\title{
PENGARUH PELATIHAN EFIKASI DIRI TERHADAP TEKANAN DARAH LANSIA HIPERTENSI
}

\author{
Ida Farida* ${ }^{*}$, Susmadi* \\ *Program Studi Keperawatan Bogor Poltekkes Kemenkes Bandung \\ $\diamond$ Corresponding Outhor: idafar1@gmail.com
}

\begin{abstract}
Banyak lansia hipertensi dalam perawatan dirinya tidak dapat mengendalikan tekanan darah. Berbagai upaya telah dilakukan, seperti pelatihan efikasi diri. Model pelatihan efikasi diri yang terdiri dari aspek kognisi, motivasi, afeksi dan seleksi dilaksanakan selama 12 sesi. Penelitian ini menggunakan metode Quasi eksperiment with control grup, melibatkan masing-masing 38 orang pada kelompok intervensi kontrol. Setelah kegiatan pelatihan efikasi diri, pada kelompok intervensi, ada perbedaan rerata tekanan darah sistolik (p-value 0,00$)$, diastolic $(0,00)$; Pada kelompok kontrol, tidak ada perbedaan rerata tekanan darah sistolik $(0,36)$, diastolik $(0,8)$; Pelatihan efikasi diri berpengaruh terhadap tekanan darah sistolik $(0,01)$ namun tidak berpengaruh pada diastolik $(0,07)$. Penelitian merekomendasikan agar perawat dapat melakukan pelatihan efikasi diri untuk membantu mengatasi masalah pada lansia hipertensi.
\end{abstract}

Kata kunci: lansia hipertensi, pelatihan efikasi diri, tekanan darah

\section{LATAR BELAKANG}

Masalah kesehatan pada usia lanjut pada umumnya terjadi pergeseran pola penyakit dari penyakit infeksi ke penyakit degenerasi. Prevalensi penyakit menular mengalami penurunan, sedangkan penyakit tidak menular (PTM) cenderung mengalami peningkatan, seperti Hipertensi.

Angka kejadian hipertensi pada lansia di Indonesia untuk umur 55-64 tahun sebesar 45,9\%, umur 65-74 tahun sebesar $57,6 \%$ dan $63,8 \%$ untuk umur di atas 75 tahun. Sedangkan angka kejadian hipertensi berdasarkan pengukuran tekanan darah pada usia $\geq 18$ tahun sebesar 25,8\% (Kemenkes RI, 2014). Berdasarkan hasil Riset Kesehatan Dasar (RISKESDAS) tahun 2018 menunjukkan angka prevalensi hipertensi hasil pengukuran mencapai $34,1 \%$ meningkat tajam dari $25,8 \%$ pada tahun 2013 (Kemenkes RI, 2018).

Angka kejadian hipertensi pada lansia di Indonesia untuk umur 55-64 tahun sebesar 45,9\%, umur 65-74 tahun sebesar 57,6\% dan $63,8 \%$ untuk umur di atas 75 tahun. Sedangkan angka kejadian hipertensi berdasarkan pengukuran tekanan darah pada usia $\geq 18$ tahun sebesar 25,8\% (Kemenkes RI, 2014). Berdasarkan hasil Riset Kesehatan Dasar (RISKESDAS) tahun 2018 menunjukkan angka prevalensi hipertensi hasil pengukuran mencapai $34,1 \%$ meningkat tajam dari $25,8 \%$ pada tahun 2013 (Kemenkes RI, 2018).

Hhipertensi apabila tidak terkontrol, akan dapat menyebabkan komplikasi seperti serangan jantung, stroke, gangguan ginjal, serta kebutaan. Dari beberapa penelitian dilaporkan bahwa penyakit hipertensi yang tidak terkontrol dapat menyebabkan peluang 7 kali lebih besar terkena stroke, 6 kali lebih besar terkena congestive heart failure, dan 3 kali lebih besar terkena serangan jantung. Hasil penelitian Sofyan, Sihombing \& Hamra (2013) menyatakan bahwa umur dan hipertensi meningkatkan resiko terjadi serangan stroke. Stroke sudah mulai muncul pada usia muda. Dalam penelitian lain dinyatakan bahwa faktor risiko dominan stroke adalah umur yang semakin meningkat, jantung koroner, diabetes melitus, hipertensi, dan gagal jantung (Ghani, Mihardja \& Delima, 2016).

Penatalaksanaan hipertensi terdiri dari dua pola pendekatan utama yaitu modifikasi gaya hidup dan pengobatan farmakologis (ESH \& ESC, 2007). Menurunkan tekanan darah dengan nilai optimal dan pengendalian utama hipertensi merupakan prioritas utama dari pelayanan kesehatan public. Self care manajemen pada klien hipertensi mengacu pada kemampuan individu untuk mempertahankan prilaku mereka yang efektif 
meliputi penggunaan obat yang dianjurkan oleh dokter, mengikuti diet dan olah raga, control secara teratur dan menjaga koping emosional dengan penyakit yang diderita (Lorig \& Holman 2003).

Self efficacy merupakan penilaian diri apakah seseorang dapat melakukan tindakan yang baik atau buruk, tepat atau salah, bisa atau tidak mengerjakan sesuai dengan yang disyaratkan (Alwisol, 2006), karena self efficacy berhubungan dengan kemampuan seseorang untuk melakukan berbagai perilaku yang menantang termasuk tindakan pencegahan dan manajemen perilaku untuk penyakit. Bila Self efficacy ini dikembangkan untuk lansia hipertensi, akan tumbuh keyakinan lansia mampu mematuhi program penatalaksanaan hipertensi sehingga lansia hipertensi dapat mengendalikan tekanan darahnya.

Hasil penelitian Rachmawati, Bashori \& Hayati (2017) mengungkapkan bahwa pelatihan efikasi diri islami dapat memberikan perubahan positif dalam menurunkan kecemasan berbicara di depan umum pada santri, memberikan motivasi untuk melakukan perubahan diri yang positif dengan memaksimalkan kelebihan yang dimiliki dan memotivasi munculnya emosi positifsehingga menghilangkan pikiran irasional.

\section{METODE}

Disain penelitian yang digunakan adalah Quasi Eksperiment with control group design dengan intervensi pelatihan efikasi diri. Peneliti memberikan intervensi yang berbeda pada dua kelompok, kemudian diamati bagaimana responnya pada akhir penelitian. Kelompok intervensi diberikan pelatihan efikasi diri sebanyak 12 sesi dengan interval 1minggu selama 3 bulan. Kelompok kontrol diberikan edukasi dan monitoring tekanan darah 1 bulan sekali selama 3 bulan sesuai standar pelayanan posbindu.

Rancangan pelatihan disusun untuk 12 pertemuan dengan interval satu minggu. Program pelatihan berfokus pada pembentukan efikasi diri, meliputi : kognisi, motivasi, afeksi dan seleksi, disertai modul pelatihan. Materi pelatihan terdiri dari : Self Care Management Hipertensi, Manajemen stres, Koping mekanism, Positif thinking, Efikasi diri, pengambilan keputusan. Metode pembelajaran yang diterapkan pada pelatihan ini adalah Ceramah, Diskusi, Simulasi, Konseling, Testimoni. Para lansia dibekali booklet sebagai buku pedoman perilaku sehat lansia hipertensi yang berisi tentang apa yang harus dilakukan, apa yang tidak perlu dilakukan, bagaimana mengatasi masalah, manajemen stres, penuntun hidup sehat dan monitoring tekanan darah.

Populasi studi pada penelitian ini adalah lansia hipertensi di Kota Bogor. Dengan jumlah sampel sebanyak 38 orang pada kelompok intervensi dan 38 orang pada kelompok kontrol. Adapun kriteria inklusi sampel adalah Lansia awal (45 th ke atas), mengalami hipertensi primer, Rerata TD > 140/90 mmHg, Bersedia menjadi responden. Kriteria Eksklusi yaitu lansia hipertensi dengan komplikasi sepeti penyakit jantung, stroke dan tidak bersedia menjadi responden.

Program intervensi dilakukan untuk kelompok intervensi berupa latihan efikasi diri tiap 1 minggu sekali selama 6 minggu pertama (kognitif \& motivasi). Dilanjutkan dengan program konseling selama $6 \mathrm{mg}$ ke-2 (afektif \& seleksi). Untuk kelompok Kontrol; dilakukan edukasi melalui pelayanan posbindu setiap bulan, selama 3 bulan. Pada akhir kegiatan penelitian kelompok control diberikan leafleat tentang latihan efikasi diri untuk lansia hipertensi.

Selama program pelatihan, setiap pertemuan disertai pengukuran tekanan darah. Pegukuran post tes dilakukan setelah jeda waktu 4 minggu untuk proses internalisasi hasil intervensi pelatihan efikasi diri lansia hipertensi. Peneliti mengukur kembali tekanan darah pada kedua kelompok. Selanjutnya data hasil penelitian dianalisis dengan uji beda dua mean. 
HASIL

\section{Analisis Univariat}

Tabel 1: Rerata Tekanan Darah Sistolik dan Diastolik sebelum dan sesudah intervensi pada kelompok intervensi dan kontrol

\begin{tabular}{|c|c|c|c|c|c|c|}
\hline \multirow{2}{*}{ Variabel } & \multicolumn{4}{|c|}{ Mean } & \multirow[b]{2}{*}{$p$} & \multirow{2}{*}{$95 \% \mathrm{CI}$} \\
\hline & Pre & Post & Selisih & SD & & \\
\hline \multicolumn{7}{|l|}{ Intervensi } \\
\hline Sistolik & 149,47 & 136,71 & 12,76 & 8,98 & 0,00 & $\begin{array}{c}9,81- \\
15,71\end{array}$ \\
\hline Diastolik & 92,37 & 86,97 & 5,39 & 6,61 & 0,00 & $\begin{array}{l}3,22- \\
7,56\end{array}$ \\
\hline \multicolumn{7}{|l|}{ Kontrol } \\
\hline Sistolik & 148,18 & 149,87 & 1,68 & 11,31 & 0,36 & $\begin{array}{c}-5,42- \\
2,03\end{array}$ \\
\hline Diastolik & 90,97 & 91,32 & 0,3 & 0,34 & 0,84 & $\begin{array}{c}-3,79- \\
3,10\end{array}$ \\
\hline
\end{tabular}

Pada kelompok intervensi, rerata tekanan darah sistolik sebelum pelatihan 149 $\mathrm{mmHg}$, setelah pelatihan $136 \mathrm{mmHg}$. Hasil analisis statistik dengan uji $t$ dependen menunjukkan nilai signifikansi 0,00 berarti ada perbedaan rerata tekanan darah sistolik sebelum dan sesudah pelatihan efikasi diri.m Sedangkan rerata tekanan darah diastolik pada kelompok intervensi, sebelum pelatihan adalah $92 \mathrm{mmHg}$, setelah pelatihan $86 \mathrm{mmHg}$. Hasil analisis statistik dengan Uji $\mathrm{t}$ dependen menunjukkan nilai signifikansi 0,00 berarti ada perbedaan rerata tekanan darah diastolik sebelum dan sesudah pelatihan efikasi diri.

Pada kelompok kontrol, rerata tekanan darah sistolik awal $148 \mathrm{mmHg}$, pada akhir kegiatan $149 \mathrm{mmHg}$. Hasil analisis statistik dengan 'Uji $\mathrm{T}$ - dependent' menunjukkan nilai signifikansi 0,36 berarti tidak ada perbedaan rerata tekanan darah sistolik sebelum dan sesudah kegiatan. Awalnya rerata tekanan darah diastolic $90 \mathrm{mmHg}$, di akhir kegiatan $91 \mathrm{mmHg}$. Hasil analisis statistik dengan 'Uji $\mathrm{T}-$ dependent' menunjukkan nilai signifikansi 0,84 berarti tidak ada perbedaan rerata tekanan darah diastolik sebelum dan sesudah kegiatan.

\section{Analisis Bivariat}

Tabel 2: Rerata Tekanan Darah Sistolik dan Diastolik pada kelompok intervensi dan kontrol setelah intervensi $(n=76)$

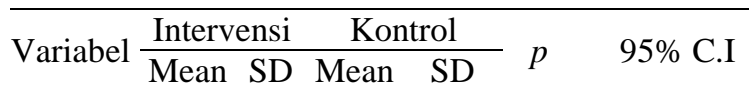

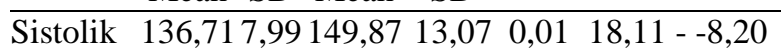
\begin{tabular}{lllll}
\hline Diastolik 86,97 4,86 91,32 & 8,75 & 0,07 & $-7,57-1,10$ \\
\hline
\end{tabular}

Rerata tekanan darah sistolik setelah pelatihan efikasi diri pada kelompok intervensi adalah $136 \mathrm{mmHg}$, sedangkan pada kelompok kontrol $149 \mathrm{mmHg}$. Hasil analisis statistik dengan 'Uji $\mathrm{T}$ Independent' menunjukkan nilai signifikansi 0,01 berarti pelatihan efikasi diri berpengaruh terhadap rerata tekanan darah sistolik.

Rerata tekanan darah diastolik setelah pelatihan efikasi diri pada kelompok intervensi adalah $86 \mathrm{mmHg}$, sedangkan pada kelompok kontrol $91 \mathrm{mmHg}$. Hasil analisis statistik dengan 'Uji $\mathrm{T}$ - Independent' menunjukkan nilai signifikansi 0,07 berarti pelatihan efikasi diri tidak berpengaruh terhadap rerata tekanan darah diastolik.

\section{PEMBAHASAN}

\section{Pelatihan Efikasi Diri}

Efikasi diri adalah Pelatihan efikasi diri untuk lansia hipertensi dirancang sebanyak 12 kali pertemuan dengan selang interval waktu 1 minggu. Bandura (1997) mengatakan bahwa orang yang memiliki efikasi diri tinggi mempunyai keyakinan mampu berperilaku tertentu untuk mencapai hasil yang diinginkan. Orang-orang yang mempunyai efikasi diri tinggi juga lebih giat dan lebih tekun dalam berusaha dan mengatasi kesulitan, serta mengerahkan tenaga yang lebih besar untuk mengatasi tantangan. Sedangkan orang yang mempunyai efikasi diri rendah cenderung mengurangi usahanya atau menyerah ketika dihadapkan pada suatu permasalahan.

\section{Tekanan Darah Sistolik}

Jantung adalah organ yang bertindak sebagai pemompa darah ke seluruh tubuh 
manusia, saat jantung memompa darah, darah tersebut akan diarahkan ke pembuluh utama yang dimulai dari vertikel kiri jantung dan kemudian memberikan darah ke organ (di arahkan ke aorta). Saat darah yang bertekanan tinggi masuk ke aorta maka akan memberikan tekanan pada dinding aorta, hal ini menyebabkan aorta mempunyai kapasitas yang elastis untuk menjadi lebih gembung dan panjang. Tekanan darah pada akhir kontraksi jantung inilah yang disebut sebagai tekanan darah sistolik (tekanan darah saat terjadi kontraksi otot jantung).

Sebelum kegiatan pelatihan dimulai, pada kelompok intervensi dan kontrol rerata tekanan darah sistolik $149 \mathrm{mmHg}$ dan 148 mmHg. Tekanan darah sistolik yang tinggi pada kedua kelompok didukung oleh stres yang dialami responden pada kedua kelompok. Pada pengukuran awal, rerata skor stress kelompok intervensi dan kontrol adalah 20 dan 16. Pada kondisi stress terjadi peningkatan aktifitas saraf simpatis yang dapat meningkatkan aktifitas denyut jantung sehingga tekanan diastolic meningkat. Makin tinggi tekanan darah sistolik menunjukkan tekanan alirah darah yag tinggi dari jantung. Pada lansia lazim terjadi peningkatan tekanan darah sistolik

Setelah kegiatan pelatihan efikasi diri berakhir, rerata tekanan darah sistolik kelompok intervensi $136 \mathrm{mmHg}$, ada selisih penurunan tekanan darah sistolik sebanyak 12,76 mmHg dengan Standar Deviasi 8,98 $\mathrm{mmHg}$. Hasil analisis statistik dengan 'Uji T - Dependent' menunjukkan nilai Sign 0,00 artinya ada perbedaan rerata tekanan darah sistolik sebelum dan sesudah pelatihan efikasi diri.

Pelatihan efikasi diri pada lansia hipertensi ini dibangun dengan 4 komponen, yaitu kognitif, motivasi, efektif dan seleksi (Bandura, 2010). Pengetahuan yang didapat dari hasil pelatihan digunakan oleh para lansia hipertensi untuk mematuhi program penatalaksanaan. Sehingga dalam waktu 3-4 bulan berikutnya tekanan darah dapat dikendalikan. Hal ini diperkuat oleh hasil penelitian Almina dan Zulhaida (2018) yang menyatakan bahwa pengetahuan berpengaruh besar terhadap pelaksanaan diet hipertensi
Sedangkan pada kelompok kontrol, rerata tekanan darah sistolik sebelum pelatihan $148 \mathrm{mmHg}$, setelah pelatihan 149 $\mathrm{mmHg}$. Hasil analisis menunjukkan nilai sign $>0,05$ artinya tidak ada perbedaan rerata tekanan darah sistolik pada saat sebelum dan sesudah pelatihan efikasi diri.

Penyuluhan kesehatan yang diberikan pada saat pelayanan posbindu ternyata belum cukup menggugah motivasi dan afeksi para lansia hipertensi untuk mengendalikan tekanan darahnya.

Pada akhir kegiatan pelatihan efikasi diri, rerata tekanan darah sistolik kelompok intervensi adalah $136 \mathrm{mmHg}$, sedangkan pada kelompok kontrol $149 \mathrm{mmHg}$ Hasil analisis menunjukkan nilai signifikansi 0,01 berarti pelatihan efikasi diri berpengaruh terhadap perbedaan rerata tekanan darah sistolik pada kelompok intervensi dan kontrol.

Pelatihan efikasi diri untuk lansia hipertensi dirancang sebanyak 12 kali pertemuan dengan selang interval waktu 1 minggu terbukti dapat membangun efikasi diri lansia hipertensi sehingga dapat mengendalikan tekanan darahnya. Hasil penelitian ini menguatkan pendapat Bandura (1997) yang mengatakan bahwa orang yang memiliki efikasi diri tinggi mempunyai keyakinan mampu berperilaku tertentu untuk mencapai hasil yang diinginkan. Orang-orang yang mempunyai efikasi diri tinggi juga lebih giat dan lebih tekun dalam berusaha dan mengatasi kesulitan, serta mengerahkan tenaga yang lebih besar untuk mengatasi tantangan. Sedangkan orang yang mempunyai efikasi diri rendah cenderung mengurangi usahanya atau menyerah ketika dihadapkan pada suatu permasalahan.

Pelatihan efikasi diri dapat membantu lansia hipertensi mematuhi pola dietnya. Hal ini didukung oleh hasil penelitian Herwati (2011) yang menyatakan bahwa terdapat hubungan yangsignifikan antara pola diet dengan terkontrolnya tekanan darah klien hipertensi.

Faktor pendukung keberhasilan kegiatan pelatihan ini adalah semangat / motivasi dan komitmen paralansia hipertensi untuk mengikuti kegiatan ini sampai dengan selesai. Pengukuran tekanan darah setiap kali 
pertemuan juga menjadi salah satu stimulus positif yang dapat mendorong langkah para lansia mengikuti kegiatan pelatihan.

\section{Tekanan Darah Diastolik}

Tekanan darah diastolik adalah tekanan yang terjadi pada akhir kontraksi jantung, pada saat otot-otot jantung sedang rileks. Normalnya tekanan darah diastolik pada lansia adalah < $80 \mathrm{mmHg}$. Peningkatan tekanan darah diastolik dihubungkan dengan beberapa hal seperti obesitas, pola makan tinggi lemak dan stress (Rigsby, B. D., 2011).

Tekanan darah diastolik sebelum pelatihan dimulai pada kelompok kontrol dan intervensi adalah 92 dan $90 \mathrm{mmHg}$. Peningkatan tekanan darah diastolik pada kedua kelompok ini dapat dianalisis karena factor stress yang didukung oleh data rerata skor stress pada kelompok intervensi dan control adalah 20 (10-44), dan 16 (10-34). Kondisi stress membuat tingkat kewaspadaan pada hipotalamus meningkat, sehingga saraf simpatis aktif bekerja, termasuk saraf simpatis yang mengontrol kerja jantung. Peningkatan aktifitas saraf simpatis dapat meningkatkan kontraksi jantung, sehingga akhir fase rileks jantung berkurang, sehingga bila dilakukan pengukuran tekanan darah, terjadi peningkatan tekanan diastolik (Dewit, 2009)

Setelah pelatihan efikasi diri berakhir, rerata tekanan darah diastolik $86 \mathrm{mmHg}$, ada selisih $5 \mathrm{mmHg}$ dengan standar deviasi 6,61. Hasil analisis statistik menunjukkan nilai signifikansi 0,00 berarti ada perbedaan rerata tekanan darah diastolik sebelum dan sesudah pelatihan efikasi diri.

Hasil penelitian ini sejalan dengan penelitian Sulistyaningsih (2011) yang mengungkapkan bahwa training efikasi diri pada pasien penyakit ginjal kronik efektifitas dalam meningkatkan kepatuhan terhadap intake cairan. Pada penelitian ini, para lansia yang pada awal kegiatan tidak teratur minum obat, jarang berolahraga , setelah dilakukan beberapa kali penyuluhan dan konseling pada pelatihan efikasi diri ini melakukan perubahan aktifitas dengan sering berjalan setiap hari minimal 30 menit, teratur minum obat, mengurangi konsumsi makanan yang berlemak. Hasil akhir dari pelatihan efikasi diri ini terlihat bahwa tekanan darah lansia hipertensi dapat dikendalikan.

Pada kelompok kontrol, Awalnya rerata tekanan darah diastolik $90 \mathrm{mmHg}$, di akhir kegiatan $91 \mathrm{mmHg}$. Hasil analisis menunjukkan nilai signifikansi 0,84 berarti tidak ada perbedaan rerata tekanan darah diastolik sebelum dan sesudah kegiatan.

Rerata tekanan darah diastolik setelah pelatihan efikasi diri pada kelompok intervensi adalah $86 \mathrm{mmHg}$, sedangkan pada kelompok kontrol $91 \mathrm{mmHg}$. Hasil analisis menunjukkan nilai signifikansi 0,07 berarti pelatihan efikasi diri tidak berpengaruh terhadap rerata tekanan darah diastolik.

Hal ini terjadi karena pengukuran tekanan diastolik dilakukan saat kondisi jantung rileks, sementara pada lansia, organ jantung termasuk pembuluh darah sudah mengalami kekakuan / kurang elastis sehingga pada akhir kontraksi jantung tidak dapat rilkes sempurna. Akibatnya saat dilakukan pengukuran tekanan darah sistolik tetap tinggi / diatas batas normal.

Secara keseluruhan, pelatihan efikasi diri pada lansia hipertensi yang telah dilakukan sebanyak 12 kali pertemuan selama 3 bulan dengan interval 1 minggu terbukti dapat merubah perilaku lansia menjadi lebih mematuhi program penatalaksaan hipertensi sehingga pada akhirnya dapat menurunkan tekanan darah sistolik. Hasil penelitian ini mendukung pendapat Huda (2017) yang menyebutkan bahwa ada hubungan antara efikasi diri dengan manajemen perawatan diri penderita hipertensi, dimana penderita dengan efikasi diri tinggi lebih mampu melakukan manajemen perawatan diri untuk penderita hipertensi.

\section{KESIMPULAN}

Pada kelompok intervensi, ada perbedaan rerata tekanan darah sistolik dan diastolik pada saat sebelum dan sesudah pelatihan efikasi diri. Sehingga disimpulkan bahwa pelatihan efikasi diri berpengaruh terhadap tekanan darah sistolik dan dan diastolik pada lansia penderita hipertensi. 
Bagi lansia hipertensi yang sudah mengikuti pelatihan efikasi diri dapat menjadi 'Role Model' bagi lansia hipertensi lainnya. Untuk perawat dapat melakukan pelatihan efikasi diri untuk mmembantu mengatasi masalah pada lansia hipertensi. Bagi pembuat kebijakan seperti Pemerintah Daerah, Dinas Kesehatan/ Puskesmas dapat menerapkan pelatihan efikasi diri pada lansia hipertensi di wilayahnya sebagai salah satu kegiatan dalam program PMT (Penyakit Tidak Menular).

\section{DAFTAR PUSTAKA}

Alwisol. (2006). Psikologi Kepribadian. UMM Press: Malang.

Bandura, A, (2010). Self Efficacy Mechanism in Psikological and Health Promoting Behavior. Prentice Hall: New Jersy.

Bandura, A. (1997). Self-Efficacy The Exercise of Control. W.H. Freeman and Company: New York.

Dewit, S. C., (2009). Medical Surgical Nursing : Concept \& Practice. Sounder Elsevier: Missouri.

ESC (2013). 2013 ESH/ESC Guidelines for the management of arterial hypertension: The Task Force for the management of arterial hypertension of the European Society of Hypertension $(\mathrm{ESH})$ and the European Society of Cardiology (ESC). Journal of Hypertension. 31: 1281-1357.

Fajar H, Diyah C, (2014). Hubungan tingkat stress dengan tekanan darah pada lansia hipertensi di Gamping Sleman Yogyakarta. Stikes Aisyiyah Yogyakarta: Skripsi

Ghani, L; Mihardja, L.K \& Delima (2016). Faktor Risiko Dominan Penderita Stroke Di Indonesia. Buletin Penelitian Kesehatan. 44(1): 49-58.

Herwati, W.S. (2014). Terkontrolnya Tekanan Darah Penderita Hipertensi Berdasarkan Pola Diet dan Kebiasaan Olahraga di Padang Tahun 2011. Jurnal Kesehatan Masyarakat. 8(1): 814.
Huda, S. (2017). Hubungan Antara Efikasi Diri Dengan Manajemen Perawatan Diri Pada Penderita Hipertensi Dewasa Di Kabupaten Jepara, Jurnal Keperawatan dan Kesehatan Masyarakat STIKES Cendekia Utama Kudus. 2(5).

Kemenkes RI. (2014). Laporan Riskesdas 2013. Balitbangkes Kemenkes RI: Jakarta.

Kemenkes RI. (2019). Laporan Riskesdas 2018. Balitbangkes Kemenkes RI: Jakarta.

Lorig, R. K. and Holman, R, Halsted. (2003). Self-management: History, Definition, Outcomes and Mechanisms. Journal self-management Education 26(1).

Rachmawati, F.A; Bashori, K \& Hayati, E.N. (2017). Pelatihan Efikasi Diri Islami Untuk Menurunkan Kecemasan Berbicara di Depan Umum Pada Santri. Jurnal Intervensi Psikologi. 9(1): 5263.

Rigsby, B. D., (2011). Hipertensi Improvement through Health Lifestyle Modification.

Sofyan, AM; Sihombing, IY \& Hamra,Y. (2013). Hubungan Umur, Jenis Kelamin, Dan Hipertensi Dengan Kejadian Stroke. Medula. 1(1): 24-30.

Sulistyaningsih, D.R (2011). Efektifitas training efikasi diri pada pasien penyakit ginjal kronik dalam meningkatkan kepatuhan terhadap intake cairan. Skripsi, Universitas Gajah Mada, Yogyakarta

Tarigan, AR; Lubis, Z \& Syarifah. (2018). Pengetahuan, Sikap dan Dukungan Keluarga Terhadap Pelaksanaan Diet Hipertensi, Jurnal Kesehatan. 11(1): 917. 